\title{
The Effect of Green Bean Flour Proportion (Vigna Radiate L.) on Acceptance, Water Content, and Fiber Content on Purple Sweet (Ipomea Batatas L. Poir) Sponge Cakes
}

\author{
Enggar Anggraeni, Cucuk \\ Suprihartini, Salsabilla Chika \\ Kartika \\ Akademi Gizi Karya Husada \\ Kediri, Kediri, Indonesia \\ Email: \\ salsabilla.chika21@gmail.com
}

Received : October $4^{\text {nd }} 2021$

Accepted : October $15^{\text {rd }} 2021$

Published : November $27^{\text {th }} 2021$

\begin{abstract}
Purple sweet potato is one type of sweet potato that is widely grown in Indonesia. Sweet potatoes are basically rich in carbohydrates, minerals, and vitamins, but poor in protein and fat. To enrich the nutritional content, especially the fiber content of sweet potatoes, can be added from beans, one of them is green beans. Observing the high nutritional and fiber content of purple sweet potatoes and green beans, it can be a new innovation and sponge cake products can be made as a high-fiber functional food. This study used an experimental method with a completely randomized design (CRD) using 3 treatments which were then tested for organoleptic acceptance, water content, and fiber content testing. The results showed that the proportion of addition of green bean flour (Vigna Radiata $L$ ) did not affect the acceptability or receptivity of color, aroma, taste, and texture. The results of the water content test of sponge cake products in the control treatment without the addition of green bean flour $(0 \%)$ had an average water content of $42.66 \%$, treatment 1 with the proportion of adding green bean flour $(15 \%)$ had an average water content of $43,44 \%$, and in treatment 2 with the addition proportion of green bean flour (30\%) has an average moisture content of $36.99 \%$. The results of the calculation of the fiber content of sponge cake products in the control treatment without the addition of green bean flour $(0 \%)$ had a total of 1.62 grams, treatment 1 with the proportion of addition of green bean flour $(15 \%)$ had an amount of 2.19 grams, and 2 with the proportion of addition of green bean flour $(30 \%)$ has a total of 2.76 grams.
\end{abstract}

Keywords: Green bean flour, purple sweet potato flour, sponge cake
Copyright (C) 2021 IIK STRADA Indonesia All right reserved.

This is an open-acces article distributed under the terms of the Creative Commons AttributionShareAlike 4.0 International License.

\section{INTRODUCTION}

Purple sweet potato is one type of sweet potato that is widely grown in Indonesia. Purple sweet potatoes can be used in any kind of food. However, people have not processed it optimally. To enhance the sweet potato consumption in Indonesia, the variety of it's product shall be more varied. In line with technology advances, there has been created the sweet potato flour to prolong the storability and make it easier to mix with other ingredients to enhance the nutritious content. 
Basically, sweet potatoes are rich in carbohydrates, minerals, and vitamins, but poor in protein and fat. So, the consumption needs to be accompanied by other foodstuffs which are rich in protein such as beans. To enrich the nutritional content, especially the fiber content of sweet potatoes, can be added from beans because they have insoluble fiber. One of them is green beans (Winarti, 2010).

Diversification of processed food based on green beans needs to be enhanced to maximize the utilization. The processing of green bean into green bean flour is to increase the usability, usage value, easier to process into high economic value, and easier to mix with other flours or foodstuffs.

Sponge cake is one of the bakery products made from flour, sugar, and egg. This time, sponge cake commonly still uses wheat flour. Wheat flour is an import product made from wheat. To reduce imports and the dependence of wheat flour to make sponge cake, purple sweet potatoes and green beans can be used as the alternative. They also increase the variations and increase the nutritions such as high fiber.

\section{MATERIALS AND METHODS}

a) Research Design

This study used an experimental method with a completely randomized design (CRD) using 3 treatments which were then tested for organoleptic acceptance, water content, and fiber content testing.

b) Tools and Material

The tools used to make sponge cake: mixer, digital scales, tablespoons, oven, stoves, pans, bowls, and sieve. The instrument for the acceptance test is an organoleptic test form which is given to the panelists who have passed the selection. The tools to do the water content test are digital scales, oven, porcelain cup, porcelain spoon, mortar, desiccator, and wood clamp. The instruments for fiber content test are table of Konsumsi Pangan Indonesia and calculator. The ingredients used in the process of making sponge cake are: purple sweet potato flour, green bean flour, all purpose flour, butter, sugar, egg, vanilla extract, emulsifier, and baking powder.

c) Place of Research

The determination of the formulation and production of sponge cakes and the acceptance test will be carried out at the Food Technology Science Laboratory of the Akademi Gizi Karya Husada Kediri. This research was conducted in December 2020.

d) Research Stages

1. Determination of Sponge Cakes Formulation

The materials used in the process of making sponge cakes:

1) Green Bean Flour

2) Purple sweet potato flour

3) Additional ingredients are all purpose flour, butter, sugar, egg, vanilla extract, emulsifier, and baking powder

2. Sponge Cakes Making

The process of making these sponge cakes begins with mixing the ingredients, which consists of sugar, eggs, and vanilla extract. Baking powder, and emulsifier for five minutes. Then, add the green bean flour and purple sweet potato flour. The "0" conditioning consists of $70 \%$ wheat flour, $30 \%$ purple sweet potato flour, and $0 \%$ green bean flour. The "1" conditioning consists of 55\% wheat flour, $30 \%$ sweet potato flour, and $15 \%$ green bean flour. The "2" conditioning consists of $40 \%$ wheat flour, $30 \%$ sweet potato flour, and $30 \%$ green bean flour. All of the ingredients are mixed again for a minute. Add the room temperature melted butter and stirred with spatula quickly. If it is well mixed, pour in the cake pan which is already covered by baking paper. Bake for \pm 45 minutes at a temperature of $160^{\circ} \mathrm{C}$.

\section{Acceptability Test}

The consumer's preference for purple sweet potato sponge cake products with various formulas of green beans flour through the senses of eyesight, taste, touch, smell. Includes color, aroma, texture and taste. 
4. Water Content Test

The calculation of the water content test is done based on a formula to know the difference between the three conditionings. Water content test is calculated using the Anova statistical test as the hypothesis testing.

5. Fiber Content Test

Fiber Content Test done by calculating the composition of the sponge cake using a calculator based on a table of Komposisi Pangan Indonesia (TKPI). The result of the calculation then compared to the percentage of average daily fiber requirement in the table of Angka Kebutuhan Gizi (Indonesia version).

\section{RESULTS}

This research used the addition of purple sweet potato flour and green bean flour on sponge cake making as one of the innovative and functional high fiber food products. The additional alternative flour on this sponge cake is $30 \%$ of purple sweet potato flour and green bean flour as much as $15 \%$ and $30 \%$.

The purple sweet potato sponge cakes formulation of the substitution of green bean flour that has been made is then carried out an organoleptic test to see its acceptability. Organoleptic test or sensory analysis of a product which includes color, taste, aroma, and texture.

Organoleptic tests were carried out using a score scale of 1 - 3 with categories of dislike, somehow like, and like. Organoleptic tests were carried out on the three formulations of purple sweet potato sponge cakes substituting green bean flour, namely P0, P1, and P2.

\section{Acceptance or Receptivity (taste assessment)}

\section{a. Color}

Table 1. Panelists' Preferred Level of Sponge Cake Color

\begin{tabular}{cccc}
\hline & \multicolumn{3}{c}{$\begin{array}{c}\text { Panelists' Preferred Level of } \\
\text { Sponge Cake Color }\end{array}$} \\
\cline { 2 - 4 } Replication & p0 0\% & p1 15\% & p2 30\% \\
\hline I & 2,43 & 2,3 & 2,37 \\
\hline II & 2,33 & 2,43 & 2,33 \\
\hline III & 2,43 & 2,33 & 2,33 \\
\hline total & 7,19 & 7,06 & 7,03 \\
\hline average & 2,39 & 2,35 & 2,34 \\
\hline
\end{tabular}

Based on the table, data showed that the highest color average $(2,39)$ is on the sponge cake made without the addition of green bean flour $(0 \%)$. It means that the sponge cake without green bean flour is the most liked by panelists. This may be caused by the better visual than the sponge cake with green bean flour. However, there is a small difference in the average color difference between the conditionings.

The preferred level average score in color of the sponge cake tends to decrease along with the addition of green bean flour. Further explanation can be seen in the graphic below.

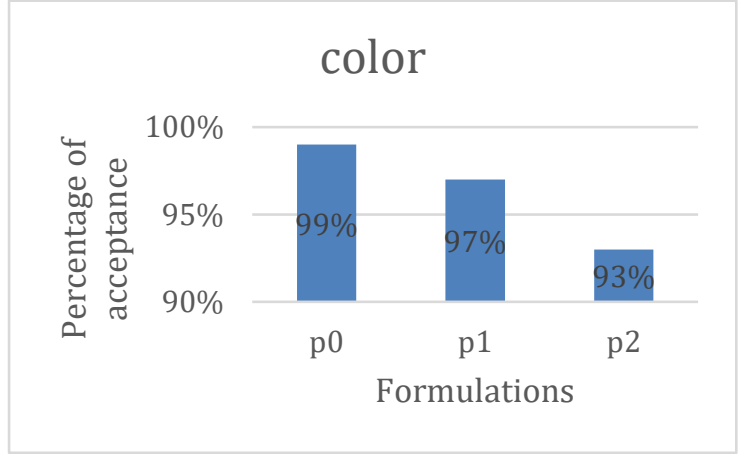

The graphic above showed that the sponge cake without the addition of green bean flour $(0 \%)$ got the highest percentage (99\%). In the "1" conditioning with the addition of green bean flour (15\%) got $97 \%$ and the " 2 " conditioning with $30 \%$ addition of green bean flour got $93 \%$. 


\section{b. Scent or Smell}

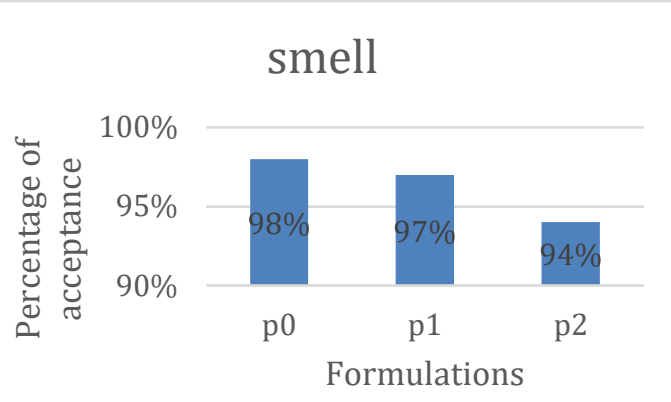

In the graphic above, the smell appraisal aspect in sponge cake without the addition of green bean flour $(0 \%)$ got the highest score $(98 \%)$. The "1" conditioning with green bean flour $(15 \%)$ got $97 \%$. The "2" conditioning with green bean flour (30\%) got $94 \%$.

Table 2. Panelists' Preferred Level of Sponge Cake Smell

\begin{tabular}{cccc}
\hline & \multicolumn{3}{c}{$\begin{array}{c}\text { Panelists' Preferred Level of } \\
\text { Sponge Cake Smell }\end{array}$} \\
\cline { 2 - 4 } Replicatoin & p0 0\% & p1 $15 \%$ & p2 30\% \\
\hline I & 2,43 & 2,37 & 2,33 \\
\hline II & 2,57 & 2,6 & 2,57 \\
\hline III & 2,53 & 2,47 & 2,4 \\
\hline total & 7,53 & 7,44 & 7,3 \\
\hline average & 2,51 & 2,48 & 2,43 \\
\hline
\end{tabular}

Based on the table above, data showed the sponge cake without the addition of green bean flour $(0 \%)$ has the highest score $(2,51)$. It means, the sponge cake without green bean flour is the most liked by panelists.

\section{c. Flavor}

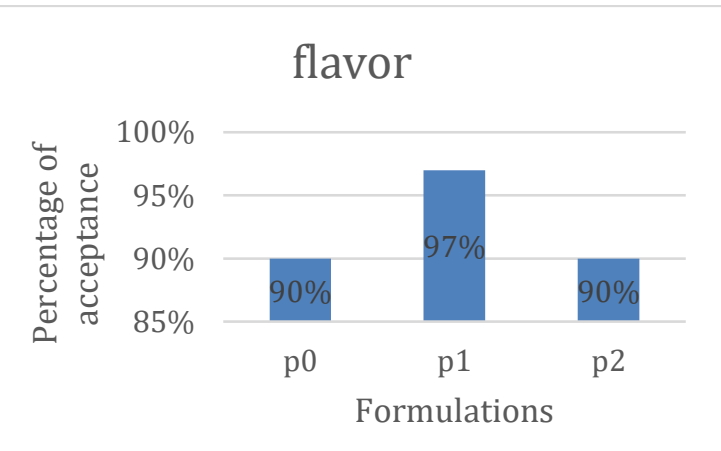

From the graphic above, sponge cake with the addition of green bean flavor $(15 \%)$ got the highest score (97\%) in the level preference flavor based from the panelists. The " 0 " conditioning which is the sponge cake without green bean flour $(0 \%)$ and the "2" conditioning which is sponge cake with $30 \%$ green bean flour got the same percentage $(90 \%)$.

Table 3. Panelists' Preference Level for Sponge Cake Flavor

Panelists' Preference Level for Sponge Cake Flavor

\begin{tabular}{cccc} 
Replication & p0 0\% & p1 15\% & p2 30\% \\
\hline I & 2,5 & 2,47 & 2,37 \\
\hline II & 2,33 & 2,53 & 2,37 \\
\hline III & 2,33 & 2,63 & 2,43 \\
\hline total & 7,16 & 7,63 & 7,17 \\
\hline average & 2,39 & 2,54 & 2,39 \\
\hline
\end{tabular}

Based on the graphic above, it showed that sponge cake with the addition of green bean flour (15\%) got the highest average score $(2,54)$. It means that the sponge cake with $15 \%$ green bean flour is 
the most liked by the panelists. The flavor in the "0" conditioning is only sweet comes from the purple sweet potato and there is no savory taste because there is not any addition of green bean flour. Purple sweet potato flour has a sweet taste that affects the flavor of the food. The "1" conditioning has a sweet taste. The " 2 " conditioning is savory and less sweet than the " 1 " conditioning because the addition of the green bean flour is more than the purple sweet potato flour.

Green bean flour which is high in protein and purple sweet potato which is high in carbohydrates will give the sweet and savory taste because of their nutritions that are high in fiber. flavor which is the combination between protein from green bean flour and carbohydrates will give the sweet and savory sensation inside our mouth (Chambers and Koppel, 2012). The perfect addition of green bean flour and purple sweet potato flour will give the unique taste on the sponge cake so the panelists loved it.

\section{d. Texture}

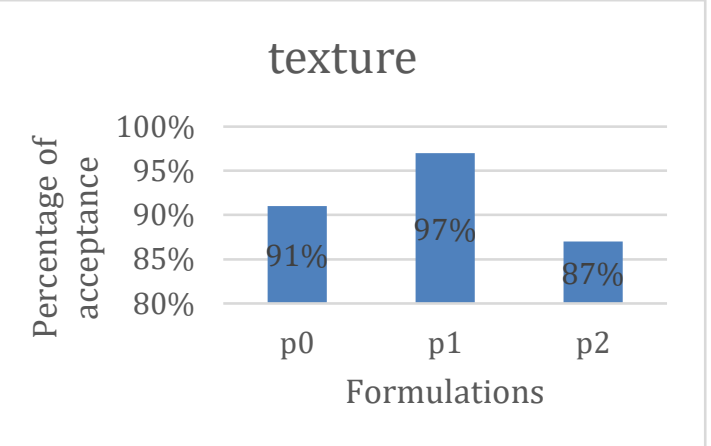

From the graphic above, sponge cake with the addition of green bean flavor (15\%) got the highest score (97\%) in the level preference flavor based from the panelists. The " 0 " conditioning which is the sponge cake without green bean flour $(0 \%)$ and the "2" conditioning which is sponge cake with $30 \%$ green bean flour got the same percentage $(87 \%)$.

Table 4. Panelists' Level of Preference for Sponge Cake Texture

\begin{tabular}{cccc}
\hline \multirow{2}{*}{ Replicatoin } & \multicolumn{3}{c}{$\begin{array}{l}\text { Panelists' Level of Preference } \\
\text { for Sponge Cake Texture }\end{array}$} \\
\cline { 2 - 4 } & p0 0\% & p1 15\% & p2 30\% \\
\hline I & 2,63 & 2,57 & 2,3 \\
\hline II & 2,43 & 2,5 & 2,47 \\
\hline III & 2,43 & 2,6 & 2,27 \\
\hline total & 7,49 & 7,67 & 7,04 \\
\hline average & 2,49 & 2,55 & 2,35 \\
\hline
\end{tabular}

Based on the graphic, it showed that sponge cake with the addition of green bean flour (15\%) got the highest score $(2,55)$. It means that the sponge cake with the $15 \%$ addition of green bean flour is the most liked by the panelists.

The texture of the sponge cake in the " 0 " conditioning was a little hard and dense. However, the texture in "1" conditioning was softer. In " 2 " conditioning, the sponge cake was less dense and fragile compared to the " 1 " conditioning. The addition of purple sweet potato will make the texture softer and dense. Whereas, the more addition of green bean flour will make the texture less dense or even fragile.

\section{e. Water Content}

Table 5. Water Content Analysis

\begin{tabular}{ccccc}
\hline Con & Rep 1 & Rep 2 & Rep 3 & Average \\
\hline P0 & 43,33 & 41,33 & 43,33 & 42,66 \\
\hline P1 & 43,67 & 46,00 & 40,67 & 43,44 \\
\hline P 2 & 35,33 & 37,33 & 38,33 & 36,99 \\
\hline
\end{tabular}


Based on the table above, it showed that sponge cake in the "2" conditioning on the first, second, and third replication, showed that the level of water content fulfil the quality requirements of the sponge cake according to SNI Sweat Bread 01-3840-1995 a maximum of 40\%. Whereas, in the "0" and "1" conditioning, the water content did not fulfil the requirements because they exceeded the limit (40\%) on every replication. The three conditioning had a different average of water content. The differences depended on the addition of the green bean flour proportion. While the addition of purple sweet potato flour in every conditioning was the same (30\%).

\section{f. Fiber Content}

Table 6. Fiber Content Analysis

\begin{tabular}{cc}
\hline Conditioning & Fiber $(\mathrm{g})$ \\
\hline P0 & 1,62 \\
P1 & 2,19 \\
P2 & 2,76 \\
\hline
\end{tabular}

Source: Calculation Results

Based on the calculation, the highest fiber content was on the " 2 " conditioning (2,76 grams). The fiber content in " 1 " conditioning is 2,19 grams. The lowest fiber content is 1,62 grams in the " 0 " conditioning. On the table above, the closest fiber intake to snacks, which is $10 \%$ of the total requirement, is on the " 2 " conditioning. The " 2 " conditioning had the highest result compared to others conditioning.

\section{DISCUSSION}

The color resulting from the sponge cake without green bean flour was brighter than the sponge cake with green bean flour. The more green bean flour added in the batter, the more the sponge cake is not liked. This is because the more green bean flour added, the darker the sponge cake will be. This color change is because of the Maillard reaction. Maillard reaction happens when there is a reaction between carbohydrates (reducing sugars) and amino groups that results in browning in cookies and other cakes (Winarno, 2002). Besides that, the dark color on foods are caused by amylose and anthocyanins which are the source of green pigments in green beans. Amylose is negatively correlated with color and gloss. The higher the content of amylose, the less attractive and shiny the color (Haryadi, 2006) This result is different from the previous research held by Sahri Yanti (2019). In the previous research, the addition of green bean flour in the making of sponge cake affected the color receptivity.

The aroma or the flavour of sponge cake without green bean flour has a unique scent and has the sweetness from the purple sweet potatoes. Whereas, the sponge cake with green bean flour has an ordinary aroma. This result is inline with the previous research held by Sahri Yanti (2019). The usage of green bean flour in sponge cake didn't affect the scent receptivity.m Purple sweet potato flour has a stronger scent compared to green bean flour. As well as the research held by Khairunnisa (2016), sponge cake with green bean flour was less liked because of its aroma.

Basically, green beans have a distinctive aroma. This is because of the lipoxygenase enzymes that produce the distinctive aroma (Kritiastuti, Dwi et al. 2013). Besides that, the addition of too much green bean flour can lead to a distinctive aroma which is slightly unpleasant and can affect the aroma of a product (Nadimin, 2014)

The panelists gave different scores to the texture of the sponge cake. The difference in texture of the sponge cake is caused by the difference in the addition of the purple sweet potato flour and green bean flour. The addition of the different flour will lead into the differences nutritions content such as carbohydrates and protein. This finding is inline with the statement from Fellow and Mayangsari (2015)) that the food texture depends on the water content, fat, and carbohydrates (cellulose, starch, and pectin), and also the protein.

Purple sweet potato flour is high in fiber that makes the sponge cake texture soft. Dietary fiber is also used to fix the food texture. Microscopically, the structure of fiber is capillaries and has more ability to absorb water. Fiber has a wide surface so that the ability to absorb water is higher (Darojat, 2010). 
The water content differences in every conditioning were beacused of several factors such as ingredient composition and product thickness. The " 0 " conditioning was high in water content because there was not any addition of green bean flour. The differences of water content is due to the differences in the content of amylose and amylopectin in the ingredients. Amylose and amylopectin affect the water content in the sponge cake. In line with the statement from Akubor (Pradipta, 2015), amylose is easy to absorb and release water and amylopectin is difficult to absorb water but water will be retained when it is absorbed. The amylose in " 0 " conditioning is less than the amylose in " 1 " and " 2 " conditioning. The more usage of green bean flour, the lower water content is. The less usage of green bean flour, the higher the water content is. Accordingly, the $30 \%$ proportion of green bean flour reached the standard value $(36,99 \%)$ of water content based on SNI (National Indonesian Standart).

The daily fiber requirement according to the 2019 RDA for men is 37 grams and for women it is 29 grams. The percentage of fiber intake in the RDA for snacks is $10 \%$ of the total requirement. In the calculation of the total fiber content, in treatment 2 there was the highest fiber content because it had the highest result.

The results of the analysis carried out on the fiber content of purple sweet potato flour reached 4.72\% (Susilowati and Medikasari, 2008). The use of purple sweet potato flour as a substitute for flour is expected to have the characteristics of a high-fiber sponge cake, because purple sweet potato contains oligosaccharides that act as prebiotics.

According to Muchtadi (2005), oligosaccharides that are not digested and absorbed in the small intestine, will be fermented by bacteria found in the large intestine, which will then change the composition of intestinal bacteria where beneficial bacteria, namely bifidobacterium (bifidus bacteria) and lactobacillus increase in number, while Harmful bacteria such as clostridium, coliform and enterococci decreased in number. Therefore, this cake can be used as functional food (functional food), because it can stimulate the growth of good bacteria for the intestines so that the absorption of nutrients becomes better and the intestines are cleaner.

\section{CONCLUSION}

Based on Kruskall Wallis statistical test, there is a result that the addition of green bean flour (Vigna Radiata $L$ ) is not affected to the color, scent, flavor, and texture receptivity on sponge cake. Based on the water content test, there is an influence between the addition of green bean flavor and the water content average on the sponge cake. From the three conditioning, only the "2" conditioning fulfills the water content requirements based on SNI $(36,99 \%)$. Based on a calculation of fiber content based from AKG in 2019, the " 0 " conditioning has 1,62 grams of fiber. The fiber content in "1" conditioning is 2,19 grams. On the " 2 " conditioning has 2,76 grams of fiber. Based on the research which has three conditioning, it can be concluded that the "1" conditioning was the most liked by the panelists because the sponge cake has good receptivity based on flavor, texture, better scent, and better color compared by the others.

\section{REFERENCES}

AKG, (2019). Angka Kecukupan Gizi yang Dianjurkan bagi Bangsa Indonesia. Jakarta: Kementrian Kesehatan Republik Indonesia.

Chambers DH dan Koppel K. (2012). Flavor comparison of natural cheeses manufactured in different countries. J Food Science. 77: 177-187.J. Clerk Maxwell, A Treatise on Electricity and Magnetism, 3rd ed., vol. 2. Oxford: Clarendon, 1892, pp.68-73.

Darojat, D. (2010). Manfaat Penambahan Serat Pangan pada Produk Daging Olahan. Majalah Food Review. 5 (7): 52-53.K. Elissa, "Title of paper if known," unpublished.

Haryadi. (2006). Teknologi Pengolahan Beras. Yogyakarta.: Gadjah Mada University Press. Khairunnisa. (2016). Uji Organoleptik Muffin Casein Gluten Free Dari Tepung Ubi Jalar Ungu dan Tepung Kacang Hijau. Bandung: Karya Tulis Ilmiah Poltekkes Kemenkes Bandung.

Kritiastuti, Dwi dan Retno Isti Komah, (2013). Pengaruh Substitusi Tepung Kacang Hijau Terhadap Tingkat Kesukaan Kue Jongkong. Universitas Negeri Surabaya. Surabaya.

Mayasari, R. (2015). Kajian Karakteristik Biskuit yang Dipengaruhi Perbandingan Tepung Ubi Jalar (Ipomea batatas L.) dan Tepung Kacang Merah (Phaseolus vulgaris L.). Bandung: Program Studi Teknologi Pangan. Fakultas Teknik. Universitas Pasundan. 
Muchtadi, Deddy. (2005). Oligosakarida Yang Menyehatkan. Bogor: Department of Food Science and Technology Institut Pertanian Bogor.

Nadimin, Ayu Dara, Rauf Suriani, (2014). Daya Terima Konsumen Dodol Multi Gizi. Media Guzi Pangan, Vol. XIII.

Pradipta, I. B. (2015). Pengaruh Proporsi Tepung Terigu dan Kacang Hijau serta Substitusi dengan Tepung Bekatul dalam Biskuit. Jurnal Pangan dan Agroindustri.

Susilawati dan Medikasari, (2008). Kajian Formulasi Tepung Terigu dan Tepung dari Berbagai Jenis Ubi Jalar Sebagai Bahan Dasar Pembuatan Biskuit Non-Flaky Crackers. Prosiding Seminar Nasional Sains dan Teknologi II 2008. Universitas Lampung. Lampung.

Winarno F. G, (2002). Ilmu Pangan dan Gizi. Jakarta: Gramedia Pustaka Utama.

Winarti Sri, (2010). Makanan Fungsional. Jakarta: Graha Ilmu.

Yanti Sahri, Hastuti, Wahyuni. (2019). Pengaruh Penambahan Tepung Kacang Hijau terhadap Karakteristik Bolu Kukus Berbahan Dasar Tepung Ubi Kayu. Sumbawa: Jurnal Tambora Vol. 3 No. 3 Fakultas Teknologi Pertanian Universitas Teknologi Sumbawa. 